\title{
PENERAPAN KUALITAS DAN HARGA TERHADAP KEPUTUSAN PEMBELIAN RUMAH OLEH KONSUMEN PADA PT PUTERA KARYASINDO PRAKARSA BATAM
}

\author{
${ }^{1}$ Rony Prasetyo, ${ }^{2}$ Anggia Arista \\ ${ }^{1}$ Universitas Putera Batam
}

prasinda@gmail.com

\begin{abstract}
The focus of this study is to determine whether the quality of products, product prices can influence the decision to purchase the home either partially or simultaneously by consumers in PT. Putera Karyasindo Prakarsa - Batam. the sample to be used in this study is as many as 98 respondents. This study suspects Partially Product Quality variables positively and significantly affect consumer purchasing decisions in PT. Putera Karyasindo Prakarsa with $t$ count value 4,084 and significance 0.000. Partially Product Price variable positively and significantly influence to Consumer Purchase Decision in PT. Putera Karyasindo Prakarsa with $t$ value 4,367 and significance 0,000. Simultaneously variable Product Quality and Product Price influence together to Purchasing Decision of consumer in PT. Putera Karyasindo Prakarsa with F value count 73,504 with significance level 0.000. The result of detrmination coefficient (R2) or the amount of solution that can be given the variable of quality and price (independent variable) to the problem ie the decision of home purchase by consumer (Dependent variable) equal to 0,607 or 60,7\% while the rest 39,3\% investigated in this study.
\end{abstract}

Keywords: Quality, Price, Purchase Decision

\begin{abstract}
ABSTRAK
Fokus penelitian ini adalah untuk mengetahui apakah kualitas produk, harga produk dapat mempengaruhi keputusan pembelian rumah baik secara parsial maupun simultan oleh konsumen di PT. Putera Karyasindo Prakarsa - Batam. sampel yang akan digunakan dalam penelitian ini adalah sebanyak 98 responden.Penelitian ini menduga Secara parsial variabel Kualitas Produk berpengaruh secara positif dan signifikan terhadap Keputusan Pembelian konsumen di PT. Putera Karyasindo Prakarsa dengan nilai t hitung 4,084 dan signifikansi 0,000 Secara parsial variabel Harga Produk berpengaruh secara positif dan signifikan terhadap Keputusan Pembelian konsumen di PT. Putera Karyasindo Prakarsa dengan nilai t hitung 4,367 dan signifikansi 0,000. Secara simultan variabel Kualitas Produk dan Harga Produk berpengaruh secara bersamasama terhadap Keputusan Pembelian konsumen di PT. Putera Karyasindo Prakarsa dengan nilai F hitung 73.504 dengan taraf signifikansi 0.000. dengan . Hasil Koefisien detrminasi $\left(R^{2)}\right.$ atau besarnya solusi yang dapat diberikan variabel kualitas dan harga (independent variable) terhadap permasalahan yakni keputusan pembelian rumah oleh konsumen (Dependent variable) sebesar 0,607 atau 60,7\% sedangkan sisanya 39,3\% adalah variabel lain yang tidak diteliti dalam penelitian ini.
\end{abstract}

Kata Kunci: Kualitas, Harga, Keputusan pembelian

\section{PENDAHULUAN}

Perkembangan persaingan bisnis pada abad ke-21 di Indonesia semakin ketat, karena setiap perusahaan senantiasa berusaha untuk meningkatkan pangsa pasar dan turut berkompetisi dalam meraih konsumen baru dan terus bersaing. Persaingan produk yang berkualitas dengan harga bersaing dan promosi yang menarik perhatian merupakan kunci utama dalam memenangkan persaingan yang akan dapat memberikan nilai positif yang lebih tinggi kepada konsumen dalam membuat keputusan pembelian.
Berdasarkan tingkat kehidupan masyarakat yang semakin meningkat, maka permintaan masyarakat terhadap kebutuhannya juga akan semakin tinggi. Oleh karena itu, perusahaan semakin dituntut untuk mengenali perilaku konsumen dan juga kepuasan konsumen untuk menyesuaikan kemampuan perusahaan dengan kebutuhan konsumen. Keberhasilan pemasaran suatu perusahaan tidak dapat dinilai dari seberapa banyak konsumen yang berhasil diperoleh, tetapi juga bagaimana cara mempertahankan konsumen tersebut. Perusahaan harus dapat 
menentukan strategi pemasaran yang tepat agar usahanya dapat bertahan dan memenangi persaingan, sehingga tujuan perusahaan tersebut dapat tercapai.

Kualitas produk dan harga produk yang ditetapkan oleh perusahaan adalah suatu keadaan yang terbaik berguna untuk memastikan konsumen, karena konsumen lebih mengetahui apakah kualitas tersebut dapat mencapai tujuan yang diharapkan. Semakin tinggi tingkat kualitas suatu produk, semakin tinggi juga tingkat kepastian pelanggan yang dihasilkan. Tingkat kualitas merupakan sebuah kunci juga untuk menciptakan nilai dan tingkat kepastian para pelanggan. Perusahaan harus mampu mengenali apa yang menjadi kebutuhan dan harapan konsumen. Dengan mengenali kebutuhan konsumen maka perusahaan akan dapat peningkatan yang lebih luas dalam persaingan dan juga dapat mempertahankan kualitas produk yang diminta oleh konsumen.

Kepuasan konsumen sangat pengaruh terhadap reputasi perusahaan, baik berupa produk atau jasa. Dengan memenuhi harapan atau kepuasan konsumen maka konsumen akan melakukan pembelian yang secara berkala di masa yang akan datang. Setiap konsumen akan membuat perbandingan produk terhadap suatu perusahaan baik dari segi harga ataupun kualitas produk, karna para konsumen mendapatkan informasi dari referensi orang lain, atau iklan sehingga konsumen membuat perbandingan tersebut untuk dapat keputusan akhir dalam penggunaan produk atau jasa perusahaan tersebut.

\section{TINJAUAN PUSTAKA}

\section{Perilaku Konsumen}

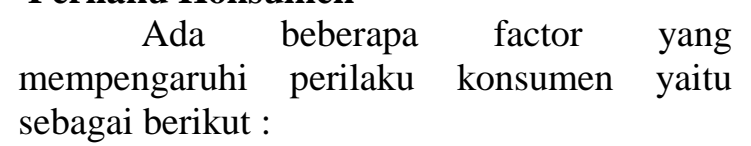

1) Faktor Budaya

Faktor budaya mempunyai pengaruh yang paling luas dan mendalam terhadap perilaku konsumen. Disini kita akan membahas beberapa peran yang dimainkan yaitu :

a) Kultur (kebudayaan) adalah determinan paling fundamental (dasar) dari keinginan dan perilaku seseorang.

b) Subkultur adalah pemberi indentifikasi dan sosialisasi yang lebih spesifik bagi anggotanya, subkultur mencakup kebangsaan, agama, kelompok ras, dan daerah geografis.

c) Kelas sosial adalah tingkatan sosial atau kelompok yang relatif homogen dan tetap dalam suatu masyarakat, yang tersusun secara hierarkis dan anggotaanggotanya memiliki nilai, minat, dan perilaku yang mirip.

\section{2) Faktor Sosial}

Perilaku konsumen juga mempengaruhi oleh faktor sosial seperti :

a) Kelompok Acuan (Kelompok Referensi) yaitu semua kelompok yang mempunyai pengaruh langsung (tatap muka) atau tidak langsung terhadap sikap atau perilaku orang tersebut. Kelompok referensi memperkenalkan perilaku dan gaya hidup baru kepada seseorang, mempengaruhi sikap dan konsep diri, dan menciptakan tekanan kenyamanan yang dapat mempengaruhi pilihan produk dan merek.

b) Keluarga yaitu merupakan kelompok acuan primer yang paling berpengaruh atau pengaruh yang lebih langsung terhadap perilaku pembelian.

c) Peran Dan Status yaitu seseorang yang berpartisipasi dalam banyak kelompok sepanjang hidupnya seperti keluarga, klub, dan organisasi yang dapat ditentukan berdasarkan peran dan status.

\section{3) Faktor Pribadi}

Keputusan pembelian juga di pengaruhi oleh karakteristik pribadi yaitu :

a) Usia dan Tahap Siklus Hidup yaitu selera dalam makanan, pakaian, perabot dan rekreasi sering berhubungan dengan usia. Konsumsi juga dibentuk oleh siklus hidup keluarga dan jumlah, usia serta jenis kelamin orang dalam rumah tangga pada satu waktu tertentu.

b) Pekerjaan dan Kondisi Ekonomi yaitu Pekerjaan juga mempengaruhi pola konsumsi. Sedangkan pilihan produk sangat dipengaruhi oleh keadaan ekonomi seperti penghasilan yang dapat dibelanjakan (tingkat, stabilitas dan pola waktu), tabungan dan asset (termasuk persentase aset 
likuid), utang, kekuatan pinjaman dan sikap terhadap pengeluaran dan tabungan.

c) Gaya Hidup (lifestyle) adalah pola hidup seseorang di dunia yang tercermin dalam kegiatan, minat dan pendapat. Keputusan konsumen juga dipengaruhi oleh nilai inti, sistem kepercayaan yang mendasari sikap dan perilaku.

d) Kepribadian dan Konsep Diri yaitu setiap orang mempunyai karakteristik pribadi yang mempengaruhi perilaku pembeliannya. Sebagai sifat seperti kepercayaan diri, dominasi, otonomi, rasa hormat, kemampuan pertahanan, dan kemampuan beradaptasi.

\subsubsection{Proses Keputusan Pembelian}

Berbagai pengaruh terhadap pembeli dan mengembangkan pemahaman tentang bagaimana sebenarnya konsumen membuat keputusan pembelian mereka, pemasar harus mengindentifikasi siapa yang membuat keputusan pembelian, jenis keputusan pembelian, dan langkah-langkah dalam proses pembelian. Gambar dibawah ini dapat kita lihat beberapa tahap dalam proses keputusan pembelian atau di sebut juga suatu "Model Tahapan".

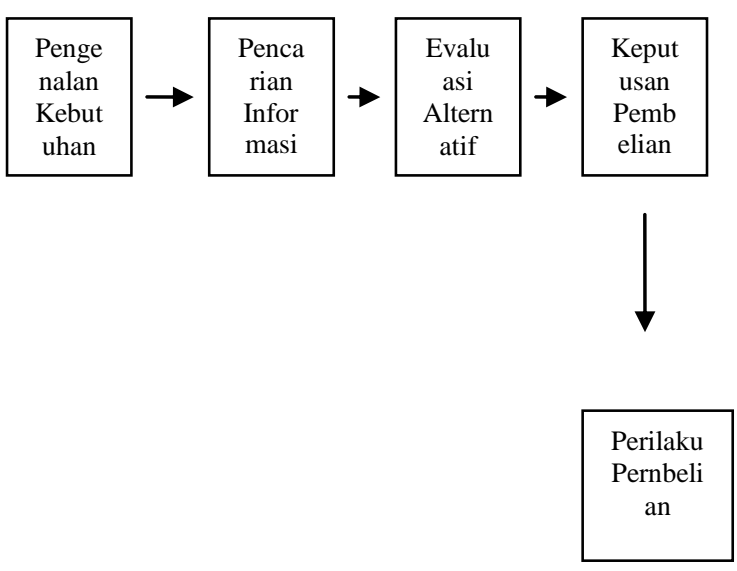

\section{Gambar 2.1 Lima Tahap Proses Keputusan} Pembelian

\section{Kualitas Dan Harga Produk 1) Produk}

Produk dapat kita definisikan sebagai segala sesuatu yang dapat ditawarkan kepasar untuk mendapatkan perhatian, dibeli, digunakan, atau dikonsumsi yang mempunya tujuan untuk memuaskan keinginan atau kebutuhan seseorang. Produk bisa berupa barang wujud yang dapat dideteksi oleh pancaindra atau tidak dapat dideteksi oleh pancaindra (contoh : jasa). Begitu juga produk mempunyai kualitas masing-masing, kulitas tersebutlah yang dapat mempengaruhi keputusan pembelian konsumen pada suatu produk yang diminta. Dimana produk yang ditawar kan jika mempunyai kualitas yang baik maka akan mendapat kan nilai positif dari konsumen dalam membuat keputusan pembeliannya terhadap produk yang diminta.

\section{2) Harga}

Harga merupakan salah satu bagian yang sangat penting dalam pemasaran suatu produk karena harga adalah satu dari empat bauran pemasaran / marketing mix atau $4 \mathrm{P}=$ product, price, place, promotion atau produk, harga, distribusi, promosi). Harga adalah suatu nilai tukar dari produk barang maupun jasa yang dinyatakan dalam satuan moneter. Harga merupakan salah satu penentu keberhasilan suatu perusahaan karena harga menentukan seberapa besar keuntungan yang akan diperoleh perusahaan dari penjualan produknya baik berupa barang maupun jasa. Menetapkan harga terlalu tinggi akan menyebabkan penjualan akan menurun, namun jika harga terlalu rendah akan mengurangi keuntungan yang dapat diperoleh organisasi

\section{Penelitian Terdahulu}

Beberapa penelitian yang menjadi bahan perbandingan dalam penelitian yang diteliti antara lain yaitu, pada tahun 2010, Chiquita Ds Pasaribu melakukan penelitian dengan judul "Pengaruh Kualitas Produk, Harga dan Isi Extra Produk Shampoo Sunsilk Sachet Isi Extra Terhadap Minat Beli Konsumen Pada Swalayan Maju Bersama Jl. Mangkubumi Medan". Penelitian menggunakan metode kuesioner dengan teknik analisis model regresi linear berganda. Hasil uji $t$ menunjukkan bahwa variabel kualitas produk berpengaruh positif dan tidak signifikan terhadap minat beli, sedangkan variabel harga dan isi extra berpengaruh positif dan signifikan terhadap minat beli.

Aderina Lubis (2007) melakukan penelitian dengan judul "Analisis Faktorfaktor yang Mempengaruhi Keputusan 
Konsumen dalam Pembelian Sepeda Motor Merek Honda di Kota Medan". Pengumpulan data menggunakan kuesioner dengan teknik analisis model regresi linear berganda. Hasil uji t yang menunjukkan bahwa variabel harga, cara pembayaran, layanan purna jual, merek, kualitas, promosi dan nilai jual kembali menunjukkan adanya pengaruh yang positif dan signifikan terhadap keputusan pembelian sepeda motor merek Honda.

Pada tahun 2010, Made Novandri Sandya Nugraha melakukan penelitian dengan judul "Analisis Pengaruh Kualitas Produk, Harga dan Iklan terhadap Keputusan Pembelian Sepeda Motor Yamaha pada Harpindo Jaya Cabang Ngaliyan". Penelitian ini menggunakan metode kuesioner dengan teknik analisis model regresi linear berganda. Pengambilan sampel menggunakan metode purposive sampling. Hasil uji t menunjukkan bahwa variable kualitas produk, harga dan iklan menunjukkan adanya pengaruh yang positif dan signifikan terhadap keputusan pembelian sepeda motor Yamaha Penelitian. Penelitian selanjutnya di tahun yang sama dilakukan oleh Rosvita Dua Lembang (2010) dengan judul "Analisis Pengaruh Kualitas Produk, Harga, Promosi dan Cuaca terhadap Keputusan Pembelian Teh Siap Minum Dalam Kemasan Merek Teh Botol Sosro (Studi Kasus Pada Mahasiswa S1 Fakultas Ekonomi Reguler II Universitas Diponegoro)". Teknik sampling menggunakan metode non probality sampling yaitu accidental sampling. Pengumpulan data dilakukan dengan menyebarkan kuesioner dan metode analisis data dengan model regresi linear berganda menggunakan software SPSS. Hasil uji $\mathrm{t}$ menunjukkan bahwa variabel kualitas produk berpengaruh positif dan tidak signifikan terhadap keputusan pembelian, sedangkan variabel harga, promosi dan cuaca berpengaruh positif dan signifikan terhadap keputusan pembelian.

\section{METODE}

Dalam penelitian ini yang menjadi objek atau sasaran penelitian adalah pelanggan PT. Putera Karyasindo Prakarsa - Batam Centre Batam yang berjumlah 130 orang.

Teknik pengambilan sampel yang digunakan dalam penelitian ini adalah dengan random sampling, yaitu peneliti menggunakan pertimbangan sendiri.

Penelitian ini menggunakan Single - cross sectional karena untuk mengumpulkan data dari setiap elemen populasi dilakukan satu kali dalam satu kali periode penelitian. Data yang digunakan dalam penelitian ini mencakup data primer dan data sekunder. Data primer adalah data yang diperoleh langsung dari wawancara dan hasil penelitian kuisioner oleh responden. Selain data primer, penelitian ini juga menggunakan data sekunder yang diperoleh dari jurnal jurnal, buku - buku dan artikel artikel dari media cetak maupun dari internet.

\section{HASIL ANALISIS DAN PEMBAHASAN Uji Validitas}

Dalam suatu penelitian, untuk memperoleh data yang baik, maka kuesioner yang dijadikan instrumen pengumpulan data harus diuji terlebih dahulu validitas dan reliabilitasnya. Instrumen yang valid berarti alat ukur yang digunakan untuk mengukur data itu valid. Valid berarti instrumen tersebut dapat digunakan untuk mengukur apa yang seharusnya diukur. Uji validitas digunakan untuk mengukur sah atau tidaknya suatu kuesioner. Suatu kuesioner dikatakan valid jika pertanyaan pada kuesioner mampu untuk mengungkapkan sesuatu yang akan diukur oleh kuesioner (Ghozali, 2009:49).

Dalam menentukan kelayakan dan tidaknya suatu ítem yang akan digunakan biasanya dilakukan uji signifikansi koefisien korelasi pada taraf 0,05 yang artinya suatu ítem dianggap memiliki tingkat ke validan jika korelasi signifikan minimun 0,5

\section{Uji Reliabilitas}

Menurut Priyatno (2010:97), Uji reliabilitas digunakan untuk mengetahui sejauh mana konsistensi alat ukur tersebut, apakah alat pengukur yang digunakan dapat diandalkan dan tepat konsisten jika pengukuran tersebut diulang.

Bila suatu alat pengukur dipakai dua kali untuk mengukur gejala yang ama dan hasil pengukuran yang diperoleh relatif konsisten maka alat pengukur tersebut reliabel.

Menurut Ghozali (2006:42), Suatu konstruk atau variabel dikatakan reliabel jika memberikan nilai Cronbach Alpha > 0,60. 


\begin{tabular}{|l|l|l|l|l|}
\hline No & Item & $\begin{array}{l}\text { Cronbach's } \\
\text { Alpha }\end{array}$ & $\begin{array}{l}\text { Nilai } \\
\text { Kritis }\end{array}$ & Hasil \\
\hline 1 & $\begin{array}{l}\text { Kualitas } \\
\text { Produk } \\
(X 1)\end{array}$ & 0.841 & 0,6 & Reliable \\
\hline 2 & $\begin{array}{l}\text { Promosi } \\
(\mathrm{X} 2)\end{array}$ & 0.786 & 0,6 & Reliable \\
\hline 3 & $\begin{array}{l}\text { Desain } \\
(\mathrm{X} 3)\end{array}$ & 0.817 & 0,6 & Reliable \\
\hline 4 & $\begin{array}{l}\text { Keputusan } \\
\text { Pembelian } \\
(Y)\end{array}$ & 0.782 & 0,6 & Reliable \\
\hline
\end{tabular}

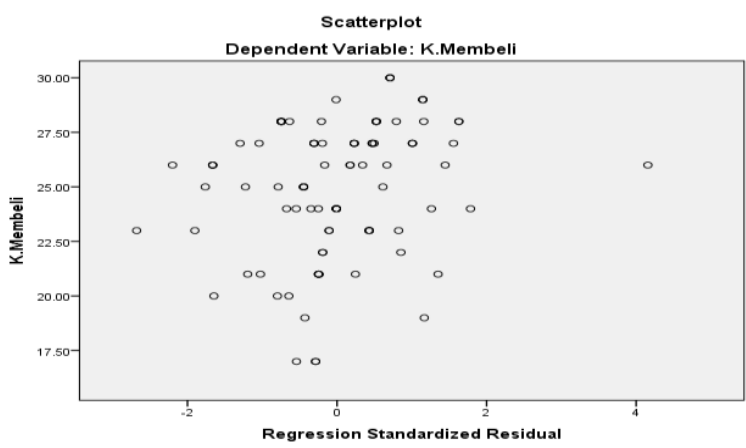

\section{Uji Asumsi Klasik}

Uji asumsi klasik yang diteliti ada empat asumsi, yaitu sebagai berikut:

\section{Uji Normalitas}

Menurut Ghozali (2006:110), "Uji normalitas bertujuan untuk menguji apakah dalam model regresi, variabel pengganggu atau residual memiliki distribusi normal. Seperti diketahui uji $\mathrm{t}$ dan $\mathrm{F}$ mengasumsikan bahwa nilai residual mengikuti distribusi normal, kalau asumsi ini dilanggar maka uji statistik menjadi tidak valid untuk jumlah sampel kecil”.

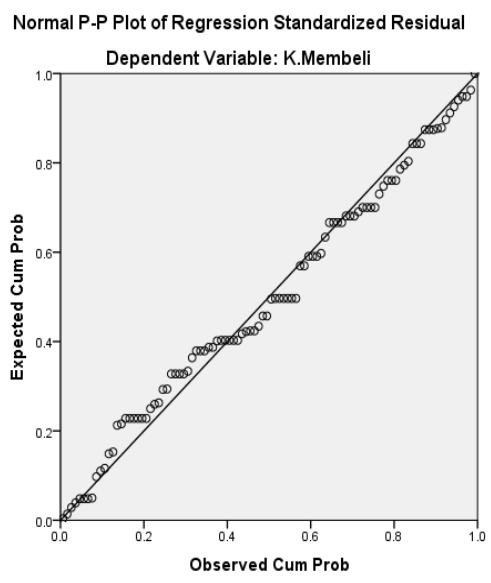

\section{Uji Heterokedastisitas}

Menurut Tony Wijaya (2011:126-127), Heteroskedastisitas menunjukkan bahwa varian variabel tidak sama untuk semua pengamatan. Jika varian dari residual satu pengamatan yang lain tetap, maka di sebut heteroskedastisitas. Model regresi yang baik adalah yang hemoskedasitisitas atau tidak terjadi heteroskedasitisitas karena data cross section memiliki data yang mewakili berbagai ukuran ( kecil, sedang dan besar ).

\section{Uji Multikolinearitas}

Menurut Ghozali (2006:124). Untuk mengetahui ada tidaknya gejala multikolinearitas dapat dilakukan dengan memperhatikan nilai matriks korelasi yang dihasilkan pada saat pengolahan data dengan melihat nilai VIF (Variance Inflation Factor) dan Tolerance-nya.

Untuk medeteksi adanya multikolinearitas dapat dilihat dari Value Inflation Factor (VIF) dan Tolerance. Apabila nilai VIF lebih besar dari 10 maka terjadi multikolinearitas, sebaliknya apabila nilai VIF kurang dari 10 maka tidak terjadi multikolinearitas. Apabila nilai tolerance lebih kecil dari 0,1 maka terjadi multikolinearitas, sebaliknya apabila nilai tolerance lebih besar dari 0,1 maka tidak terjadi multikolinearitas. VIF dan Tolerance merupakan pengukur adanya multikolinearitas antara variabel-variabel bebas.

Tabel Coefficients ${ }^{a}$

\begin{tabular}{|r|r|l|r|r|}
\hline \multicolumn{2}{|c|}{ Correlations } & \multicolumn{2}{c|}{$\begin{array}{c}\text { Collinearity } \\
\text { Statistics }\end{array}$} \\
\hline $\begin{array}{l}\text { Zero- } \\
\text { order }\end{array}$ & Partial & Part & Tolerance & VIF \\
\hline .935 & .544 & .126 & .168 & 5.970 \\
.971 & .812 & .271 & .165 & 6.045 \\
.848 & .084 & .016 & .262 & 3.817 \\
\hline
\end{tabular}

\begin{tabular}{|c|c|c|c|}
\hline \multirow{2}{*}{\multicolumn{2}{|c|}{ Model }} & \multicolumn{2}{|c|}{$\begin{array}{l}\text { Unstandardized } \\
\text { Coefficients }\end{array}$} \\
\hline & & $B$ & Std. Error \\
\hline \multirow[t]{3}{*}{1} & (Constant) & -1.361 & 1.759 \\
\hline & $\begin{array}{l}\text { Kualitas } \\
\text { produk }\end{array}$ & 0.428 & 0.105 \\
\hline & $\begin{array}{l}\text { Harga } \\
\text { produk }\end{array}$ & 0.601 & 0.138 \\
\hline
\end{tabular}


Dari tabel diatas dapat disimpulkan bahwa variabel kualitas pelayanank (X1), promosi (X2) dan desain (X3), tiga variabel bebas tersebut tidak terjadi multikolinearitas dengan ditunjukkan nilai VIF dari dua variabel bebas yaitu variabel kualitas produk dan harga produk tersebut lebih kecil dari 10 dan nilai tolerance dari dua variabel bebas yaitu variabel gaji dan insentif lebih besar dari 0,1.

\section{Uji Koefisien Determinasi $\left(\mathbf{R}^{2}\right)$}

Berdasarkan hasil dari analisis determinasi dapat dilihat pada tabel 2 dari hasil analisis regresi berganda ini, diperoleh angka $\mathrm{R}$ Square sebesar 0,607 atau $(60,7 \%)$.

Tabel Hasil Koefisien Determinasi

Model Summary ${ }^{b}$

\begin{tabular}{|l|l|l|l|}
\hline Model & $R$ & R Square & $\begin{array}{l}\text { Adjusted R } \\
\text { Square }\end{array}$ \\
\hline 1 & $0.779^{\mathrm{a}}$ & 0.607 & 0.599 \\
\hline
\end{tabular}

Hasil ini menunjukkan bahwa presentase pengaruh variabel independen (kualitas produk dan harga produk) terdapat variabel dependen (keputusan pembelian) sebesar $60.7 \%$. Atau variasi variabel independen yang digunakan dalam model (kualitas produk dan harga produk) mampu menjelaskan sebesar $60.7 \%$ variasi variabel dependen (keputusan pembelian). Sedangkan sisanya sebesar 39.3\% dipengaruhi atau dijelaskan oleh variabel lain yang tidak dimasukkan dalam model penelitian ini.

\section{Persamaan Regresi Berganda Dua Variabel} Pengujian melalui regresi linier berganda digunakan untuk menganalisis sejauh mana kualitas produk, promosi dan Desain produk terhadap keputusan pembelian rumah PT. Putera Karyasindo Pratama. Persamaan regresi kualitas produk dan harga produk terhadap keputusan pembelian dapat ditulis sebagai berikut :

Dari tabel menunjukkan persamaan regresi sebagai berikut:

$$
Y=-1.361+0.428 X_{1}+0.601 X 2+e
$$

1) $\operatorname{Constant}(\mathrm{a})=-1,361$

Angka konstanta sebesar -1,361 menunjukkan bahwa jika tidak ada pengaruh kualitas produk dan harga, maka keputusan pembelian akan menurun sebesar 1,361.

2) Kualitas Produk (X1) / $\beta 1=0,428$

Angka tersebut menunjukkan koefisien untuk variabel kualitas produk. Angka sebesar 0,428 menunjukkan bahwa tanda positif berarti apabila manajemen perusahaan meningkatkan kualitas produk sebesar 0,428 maka keputusan pembelian konsumen terhadap produk perumahan PT.Putera Karyasindo Prakarsa akan mengalami kenaikan sebesar 0,428.

\section{3 ) Variable Harga Produk (X2) / $\beta 2=0,601$}

Angka tersebut menujukkan koefisien untuk variabel Harga yang artinya, Angka sebesar 0,601 menunjukkan bahwa apabila harga produk mengalami kenaikan, maka keputusan pembelian Konsumen terhadap produk perumahan akan mengikuti kenaikan sebesar 0,601 .

\section{SIMPULAN}

Dari hasil penelitian dan pembahasan yang telah disampaikan pada bab sebelumnya, disimpulkan bahwa:

1. Secara parsial variabel Kualitas Produk berpengaruh secara positif dan signifikan terhadap Keputusan Pembelian konsumen di PT. Putera Karyasindo Prakarsa dengan nilai t hitung 4,084 dan signifikansi 0,000

2. Secara parsial variabel Harga Produk berpengaruh secara positif dan signifikan terhadap Keputusan Pembelian konsumen di PT. Putera Karyasindo Prakarsa dengan nilai t hitung 4,367 dan signifikansi 0,000 .

3. Secara simultan variabel Kualitas Produk dan Harga Produk berpengaruh secara bersama-sama terhadap Keputusan Pembelian konsumen di PT. Putera Karyasindo Prakarsa dengan nilai $F$ hitung 73.504 dengan taraf signifikansi 0.000 .

4. Hasil Koefisien detrminasi $\left(\mathrm{R}^{2)}\right.$ atau besarnya solusi yang dapat diberikan variabel kualitas dan harga ( independent variable) terhadap permasalahan yakni keputusan pembelian rumah oleh konsumen (Dependent variable) sebesar 0,607 atau $60,7 \%$ sedangkan sisanya $39,3 \%$ adalah variabel lain yang tidak diteliti dalam penelitian ini . 


\section{DAFTAR PUSTAKA}

Cooper dan Emory, 1996, Metode Penelitian Bisnis, Jakarta:Erlangga.

Indriantoro, Supomo. 1999. Metodologi Penelitian Bisnis untuk Akuntansi dan. Manajemen. Edisi Pertama. BPFE Yogyakarta. Yogyakarta.

Ferdinand, Augusty.2014. Metode Penelitian Manajemen.Bandung. Universitas Diponegoro

Nasir, Mohammad. 2003. Metodologi Penelitian. Penerbit Pustaka Pelajar. Yogyakarta

Sugiyono, Prof. Dr. 2014. Metode Penelitian Bisnis. Bandung: Alfabeta.

Umar. 1999. Metode Penelitian: Aplikasi Dalam Pemasaran. Jakarta: PT. Gramedia Pustaka Utama.

Wibowo, Agung Edy. 2012. Aplikasi Prakstis SPSS Dalam Penelitian. Yogyakarta: Gava Media. 